\title{
New section in EJNMMI and Annals of Nuclear Medicine
}

\author{
Ignasi Carrió $^{1} \cdot$ Seigo Kinuya ${ }^{2}$
}

Published online: 16 September 2016

(C) The Author(s) 2016. This article is published with open access at Springerlink.com

\section{Dear Readers,}

The EJNMMI and Annals of Nuclear Medicine are introducing a new section that brings a review of the relevant articles published last year in the respective journals. Written by guest key experts, this section is intended to offer the readers a condensed global view on the highquality research work that has been published in the other journal during the last period. We hope that this new journal feature will strengthen scientific cooperation between Europe and Japan and will be interesting and informative to the entire readership.
Ignasi Carrió, EJNMMI Editor-in-Chief

Seigo Kinuya, Annals of Nuclear Medicine Editor-in-Chief

Open Access This article is distributed under the terms of the Creative Commons Attribution 4.0 International License (http://crea tivecommons.org/licenses/by/4.0/), which permits unrestricted use, distribution, and reproduction in any medium, provided you give appropriate credit to the original author(s) and the source, provide a link to the Creative Commons license, and indicate if changes were made.
Seigo Kinuya

kinuya@med.kanazawa-u.ac.jp

1 Department of Nuclear Medicine, Autonomous University of Barcelona, Barcelona, Spain

2 Department of Nuclear Medicine, Kanazawa University Graduate School of Medical Science, Kanazawa, Japan 